\title{
T-Cell-Specific Surface Glycoprotein CD28
}

National Cancer Institute

\section{Source}

National Cancer Institute. T-Cell-Specific Surface Glycoprotein CD28. NCI Thesaurus. Code $C 17336$.

T-cell-specific surface glycoprotein CD28 (220 aa, $25 \mathrm{kDa}$ ) is encoded by the human CD28 gene. This protein is involved in the survival and activation of T-lymphocytes. 